\title{
Artur Karasiński
}

Uniwersytet Mikołaja Kopernika

Toruń

\section{Formalna analiza albańskich derywatów przymiotnikowych}

Proponowaną klasyfikację albańskich derywatów przymiotnikowych oparto na modelu opisu konfrontatywnego stworzonym przez Viarę Maldjievą na potrzeby konfrontacji języka polskiego oraz bułgarskiego i zamieszczonym w 9 tomie Gramatyki Konfrontatywnej Bułgarsko Polskiej. Artykuł jest także częścią znacznie większej pracy, poświęconej analizie semantycznej i formalnej albańskiego przymiotnika.

Kategorie gramatyczne, jakie może wyrażać albański przymiotnik na zasadzie kongruencji, dostosowując się do poprzedzającego go rzeczownika, to liczba, rodzaj i przypadek. Ze względu na supletywizm kategoryzacja ta jest jednak niedoskonała. Naturalnie, z punktu widzenia opisu formalnego klasy gramatycznej przymiotnika większość gramatyk albańskich dzieli przymiotniki przede wszystkim na rodzajnikowe i bezrodzajnikowe. $Z$ punktu widzenia charakterystyki klasy gramatycznej przymiotnika w języku albańskim jest to podejście słuszne - i rzeczywiście, wprowadzenie klasyfikacji wychodzącej od podziału na typ rodzajnikowy i bezrodzajnikowy należy uznać za uzasadnione. Jednak gdy przedmiotem zainteresowania jest derywacja, tak jak ma to miejsce $\mathrm{w}$ tym artykule, istotna okazuje się nie tylko wnikliwa charakterystyka formalna 
segmentalnych wykładników derywacji, lecz także refleksja nad tym, w jaki sposób rodzajnik prepozytywny ${ }^{1}$ pełni funkcję słowotwórczą. Tak więc rodzajnik prepozytywny, choć - w przeciwieństwie do rodzajnika postpozytywnego ${ }^{2}$ - nie dołączany do wyrazu, należy do grupy jednostek leksykalnych, jakimi są przymiotniki rodzajnikowe, i będzie traktowany jako wykładnik paradygmatyczny przynależny tej właśnie klasie przymiotników. Nie należy zatem do tematu przymiotnika. Forma rodzajnika prepozytywnego (masc. sg. i, fem. sg. e oraz neutr. sg i masc./fem. pl. të) zależy od liczby, rodzaju, przypadka i określoności, może więc pełnić funkcję wykładnika derywacji paradygmatycznej - takie przypadki analiza formalna albańskich derywatów przymiotnikowych ma za zadanie także wyszczególnić.

Formalny opis słowotwórczy albańskiego przymiotnika został przeprowadzony, jak już wspomniałem, na podstawie modelu zaproponowanego przez Viarę Maldjievą na potrzeby opisu słowotwórstwa konfrontatywnego dla języków polskiego i bułgarskiego. Inspirację do sformułowania formalnych struktur derywacyjnych stanowił opis technik derywowania rzeczowników odprzymiotnikowych typu nomina essendi [zob. Encyklopedia: 396], który przeprowadził Marek Wiśniewski w rozprawie Dystrybucyjne właściwości odprzymiotnikowych nazw cech we współczesnej polszczyźnie [Wiśniewski 2005: 21-24]. Dzięki wyodrębnieniu klas derywacyjnych na drodze logicznego podziału dychotomicznego, opis jest prosty i czytelny. Model, przedstawiony w Gramatyce Konfrontatywnej Bułgarsko-Polskiej, został przystosowany teoretycznie do wszystkich możliwych typów derywatów występujących w językach polskim i bułgarskim. Tym samym nadaje się do opisu wszystkich języków słowiańskich. Tu analizie według przedstawionego poniżej modelu poddane zostaną albańskie derywaty przymiotnikowe, które wyekscerpowano ze Słownika Wspótczesnego Języka Albańskiego, który został opracowany przez Instytut Języka i Literatury Albańskiej Akademii Nauk w roku 1984. (Fjalor i Shqipës së Sotmë, 1984). Jego wznowione i poprawione wydanie ukazało się w Tiranie

1 Rodzajnik prepozytywny - pełni funkcję czysto syntaktyczną. Wyróżniamy: $i$ dla rodzaju męskiego liczby pojedynczej, $e$ dla rodzaju żeńskiego liczby pojedynczej i të dla rodzaju nijakiego liczby pojedynczej oraz dla liczby mnogiej wszystkich rodzajów. Występuje przed przymiotnikami rodzajnikowymi, imiesłowami przymiotnymi i przed większością zaimków.

${ }^{2}$ Rodzajnik postpozytywny jest dołączany do rzeczowników w formie określonej, może być także dołączany do przymiotników, zarówno rodzajnikowych, jak i bezrodzajnikowych $\mathrm{w}$ formie substantywizowanej. $\mathrm{W}$ takim przypadku przymiotnik przyjmuje paradygmat fleksyjny rzeczownika - zgodnie z regułą, że morfemy fleksyjne zajmują drugą pozycję we frazie nominalnej. To, czy przymiotnik jest rodzajnikowy czy bezrodzajnikowy, zależy wyłącznie od obecności rodzajnika prepozytywnego. 
$\mathrm{w}$ roku 2002. Korpus wyekscerpowanego ze słownika materiału to blisko 62\% wszystkich adjektywnych jednostek leksykalnych w Słowniku Współczesnego Języka Albańskiego, czyli około 6100 derywatów przymiotnikowych.

W egzemplifikacji zastosowano przykłady derywatów dla rodzaju męskiego liczby pojedynczej. Jeżeli dany przymiotnik jest rodzajnikowy, to podany przykład znajduje się także w paradygmacie liczby pojedynczej rodzaju męskiego, a więc przyjmuje rodzajnik $i$. Taki sposób zapisu jest naturalnie uproszczeniem i wynika z tradycji przyjętej w większości gramatyk albańskich ${ }^{3}$. Ponadto leksykalne jednostki motywujące przynależne są formie nieokreślonej nominativu singularis. Po przecinku podawany jest morfem określoności. W kilku przypadkach, kiedy tematem derywacyjnym jest temat liczby mnogiej, podane są rzeczowniki fundujące $\mathrm{w}$ nominativie pluralis, zostaje to jednak wyraźnie odnotowane. W przypadkach, gdy motywującym wyrazem jest czasownik, jego zapis podaję z wyodrębnieniem tematu i końcówki gramatycznej ${ }^{4}$ (w przypadkach $\mathrm{z}$ afiksacją).

Formalną analizę derywatów oparto na cechach wykładników derywacji, z których wyprowadzono kryteria podziału dychotomicznego:

1. ujemność: +/- redukcja tematu,

2. alternacyjność: $+/-$ alternacje $\mathrm{w}$ temacie,

3. paradygmatyczność: +/- dodanie do tematu morfemu gramatycznego,

4. konfiksalność: +/- dodanie do tematu dwóch afiksów,

5. afiksalność: +/- dodanie do tematu afiksu określonego typu. [Maldjieva 2009: 103]

Proponowany podział z wprowadzonymi zmianami odnośnie do klas derywatów przymiotnikowych w języku albańskim, których oznaczenia podane są w nawiasach, np. $(\mathrm{A})^{5}$

${ }^{3}$ W klasie przymiotników rodzajnikowych różnica w rodzaju wynika $\mathrm{z}$ formy rodzajnika. Pomijając tę różnicę większość przymiotników rodzajnikowych nie ma różnych form w rodzaju męskim i żeńskim. Jedynie przymiotniki rodzajnikowe z sufiksami -ëm, -shëm w rodzaju żeńskim mają ich warianty dla rodzaju żeńskiego, czyli -me, -shme. Przymiotniki bezrodzajnikowe zakończone na spółgłoskę w rodzaju żeńskim przybierają końcówkę -e, np. sintetik/sintetike 'syntetyczny/a'.

4 Tego typu zapis, zarówno w przypadku klasy gramatycznej czasownika, jak i rzeczownika, ukazuje oddzielenie tematu motywującego od końcówki gramatycznej i ułatwia lekturę osobom nieznającym struktury morfologicznej języka albańskiego.

${ }^{5}$ Model z Gramatyki Konfrontatywnej Bułgarsko-Polskiej zawierający możliwe struktury derywatów został zachowany w tej samej formie [por. Maldjieva 2009: 104-105], zmianie uległy zaś oznaczenia klas derywatów wyszczególnionych wyłącznie dla albańskich derywatów przymiotnikowych. Struktura derywatów przymiotnikowych nie jest na tyle bogata, by uwzględniać wszystkich dziewiętnaście klas wyabstrahowanych we wzorcowym modelu, który dotyczył formalnej struktury wszystkich klas gramatycznych w językach polskim i bułgarskim. 


\section{Derywat}

\section{1. temat nie podlega redukcji}

\section{1. bez alternacji $\mathrm{w}$ temacie}

1.1.1. bez dodania morfemu gramatycznego 1.1.1.1. bez konfiksu

1.1.1.1.1. bez afiksu

1.1.1.1.2. z afiksem

1.1.1.1.2.1. bez prefiksu

1.1.1.1.2.1.1. bez postfiksu (A) 1.1.1.1.2.1.1.1. bez postfiksu 1.1.1.1.2.1.1.2. $\mathrm{z}$ postfiksem

1.1.1.1.2.1.2. z postfiksem

1.1.1.1.2.2. z prefiksem (B)

1.1.1.2. $\mathrm{z}$ konfiksem

1.1.2.2.1. bez sufiksu

1.1.2.2.2. z sufiksem

1.1.2.2.2.1. bez prefiksu

1.1.2.2.2.2. z prefiksem $(\mathrm{F})$
1.1.2. $\mathrm{z}$ dodaniem morfemu gramatycznego

1.1.2.1. bez konfiksu

1.1.2.1.1. bez afiksu (C)

1.1.2.1.2. $\mathrm{z}$ afiksem

1.1.2.1.2.1. bez sufiksu

1.1.2.1.2.1.1. bez prefiksu

1.1.2.1.2.1.2. z prefiksem (D)

1.1.2.1.2.2. z sufiksem (E)

1.1.2.2. $\mathrm{z}$ konfiksem

\section{2. $\mathrm{z}$ alternacją $\mathrm{w}$ temacie}

1.2.1. bez dodania morfemu gramatycznego

1.2.1.1. bez konfiksu

1.2.1.1.1. bez afiksu (...)

1.2.1.1.2. $\mathrm{z}$ afiksem [...]

1.2.1.1.2.1. bez sufiksu [...]

1.2.1.1.2.2. z sufiksem (...)

1.2.1.2. z konfiksem [...]
1.2.2. $z$ dodaniem morfemu gramatycznego

1.2.2.1. bez konfiksu

1.2.2.1.1. bez afiksu

1.2.2.1.2. $\mathrm{z}$ afiksem

1.2.2.1.2.1. bez sufiksu $[\ldots]$

1.2.2.1.2.2. $\mathrm{z}$ sufiksem

1.2.2.2. z konfiksem [...]

\section{2. temat podlega redukcji}

2.1. bez alternacji $\mathrm{w}$ temacie

2.1.1. bez dodania morfemu gramatycznego 2.1.1.1. bez konfiksu

2.2.1.1.1. bez afiksu (...)

2.2.1.1.2. $\mathrm{z}$ afiksem

2.2.1.1.2.1. bez sufiksu [...] (G)

2.2.1.1.2.2. z sufiksem (...)

2.1.1.2. z konfiksem [...]
2.1.2. $\mathrm{z}$ dodaniem morfemu gramatycznego

2.1.2.1.bez konfiksu

2.1.2.1.1. bez afiksu

2.1.2.1.2. $\mathrm{z}$ afiksem

2.1.2.1.2.1. bez sufiksu [...]

2.1.2.1.2.2. $\mathrm{z}$ sufiksem

2.1.2.2. z konfiksem [...]

2.2. $\mathrm{z}$ alternacją $\mathrm{w}$ temacie

2.2.1. bez dodania morfemu gramatycznego $\quad 2.2 .2$. $z$ dodaniem morfemu gramatycznego

2.2.1.1. bez konfiksu

2.2.1.1.1. bez afiksu (...)

2.2.1.1.2. $\mathrm{z}$ afiksem

2.2.1.1.2.1. bez sufiksu [...]

2.2.1.1.2.2. z sufiksem (...)

2.2.1.2. $\mathrm{z}$ konfiksem $[\ldots]$
2.2.2.1. bez konfiksu

2.2.2.1.1. bez afiksu

2.2.2.1.2. $\mathrm{z}$ afiksem

2.2.2.1.2.1. bez sufiksu $[\ldots]$

2.2.2.1.2.2. z sufiksem

2.2.2.2. z konfiksem [... ${ }^{\star}$

* Podział dychotomiczny przyjęty z [Maldjieva 2009: 104-105] z wprowadzonymi zmianami dotyczącymi oznaczeń klas derywatów (patrz przypis 2). 


\section{Klasy derywatów:}

\section{A - interfiksalne}

tekniko-shkencor - 'techniczo-naukowy' (Adj teknik-o-shkencor $\leftarrow$ Adj teknik + Adj shkencor)

kinezojugor - 'południowochiński' (Adj kinez-o-jugor $<$ Adj kinez + Adj jugor) amerikanoperendimor - 'zachodnioamerykański' (Adj amerikan-o-perendimor $\leftarrow$ Adj amerikan + Adj perendimor)

zviceranojugor - 'południowoszwajcarski' (Adj zviceran-o-jugor $\leftarrow$ Adj zviceran + Adj jugor)

iliro-trak - 'iliryjsko-tracki' (Adj ilir-o-trak $\leftarrow$ Adj ilir + Adj trak)

greko-romak - 'greko-romański' (Adj grek-o-romak $\leftarrow$ Adj grek + Adj romak) analitiko-sintetik - 'analityczno-syntetyczny' (Adj analitik-o-sintetik $\leftarrow$ Adj analitik + Adj sintetik) itd.

Derywaty interfiksalne utworzone zostały na drodze złożenia dwóch tematów przymiotnikowych połączonych ze sobą interfiksem -o-. Podczas procesu derywacji nie dochodzi do redukcji ani alternacji tematowych. Żaden morfem gramatyczny nie zostaje dodany, nie ma więc miejsca zmiana paradygmatu jednostki leksykalnej.

\section{B - prefiksalne}

pa-

i paafrueshëm -'nietowarzyski' (Adj i pa-afrueshëm $<$ Adj $i$ afrueshëm 'towarzyski')

i pakripur - 'niesłony' (Adj i pa-kripur $\leftarrow$ Adj i kripur 'słony')

i pakushtueshëm - 'niedrogi' (Adj i pa-kushtueshëm $<$ Adj i kushtueshëm 'drogi') i pakufishëm - 'bezgraniczny' (Adj i pa-kufishëm $\leftarrow$ Adj $i$ kufishëm 'skończony') itd.

$$
\text { jo- }
$$

jonormal - 'nienormalny' (Adj jo-normal $\leftarrow$ Adj normal 'normalny') jozyrtar - 'nieoficjalny' (Adj jo-zyrtar $\leftarrow$ Adj zyrtar 'oficjalny') jobujqesor - 'pozarolniczy'(Adj jo-bujqesor $\leftarrow$ Adj bujqesor 'rolniczy') jomiqesor - 'nieprzyjazny' (Adj jo-miqesor $\leftarrow$ Adj miqesor 'przyjazny') joorganik - 'nieorganiczny' (Adj jo-organik $\leftarrow$ Adj organik 'organiczny') 
jonjerëzor - 'nieludzki' (Adj jo-njerëzor $\leftarrow$ Adj njerëzor 'ludzki')

joparimor - 'niegodziwy' (Adj jo-parimor $\leftarrow$ Adj parimor 'godziwy')

jorealist - 'nierealny' (Adj jo-realist $\leftarrow$ Adj realist 'realny')

joprodhues - 'nieproduktywny' (Adj jo-prodhues $\leftarrow$ Adj prodhues 'produktywny')

jokryesor - 'niepodstawowy' (Adj jo- kryesor $\leftarrow$ Adj kryesor 'podstawowy') itd.

$a-$

apolitik - 'apolityczny' (Adj a-politik $\leftarrow$ Adj politik 'polityczny')

asimetrik - 'asymetryczny' (Adj a-simetrik $\leftarrow$ Adj simetrik 'symetryczny')

afetar - 'niewierzący' (Adj a-fetar $\leftarrow$ Adj fetar 'wierzący')

anormal - 'nienormalny' (Adj a-normal $\leftarrow$ Adj normal 'normalny')

itd.

para-

paralajmërues - 'prognostyczny' (Adj para-lajmërues $\leftarrow$ Adj lajmërues 'ostrzegawczy')

parandalues - 'prewencyjny' (Adj para-ndalues $\leftarrow$ Adj ndalues 'zatrzymany') parahistorik - 'prehistoryczny' (Adj para-historik $\leftarrow$ Adj historik 'historyczny') paragjuhor - 'przedniojęzykowy' (Adj para-gjuhor $\leftarrow$ Adj gjuhor 'językowy') parafolës - 'mówiący przed kimś' (Adj para-folës $\leftarrow$ Adj folës 'mówiony') itd.

Derywaty przymiotnikowe utworzone na wcześniejszym etapie derywacji od czasowników za pomocą sufiksu -ues/-yes występują w języku albańskim także w paradygmacie rzeczownikowym jako nomina essendi. Jest to kolejny etap derywacji od analizowanych w materiale przymiotników.

\section{pro-}

proamerikan - 'proamerykański' (Adj pro-amerikan $\leftarrow$ Adj amerikan 'amerykański')

prosovjetik - 'prosowiecki' (Adj pro-sovjetik $\leftarrow$ Adj sovjetik 'sowiecki') proevropian - 'proeuropejski' (Adj pro-evropian $<$ Adj evropian 'europejski') proshqiptar - 'proalbański' (Adj pro-shqiptar $\leftarrow$ Adj shqiptar 'albański') propolonisht - 'propolski' (Adj pro- polonisht $\leftarrow$ Adj polonisht 'polski') itd. 


\section{pas-}

pasuniversitar - 'podyplomowy' (Adj pas-universitar $\leftarrow$ Adj universitar 'uniwersytecki')

pastheksor - 'poakcentowy' (Adj pas-theksor $\leftarrow$ Adj theksor 'akcentowy')

i paslindur - 'urodzony później' vs. i paralindur 'urodzony wcześniej' (Adj

$i$ pas-lindur $\leftarrow$ Adj $i$ lindur 'urodzony')

paszgjedhor - 'powyborczy' (Adj pas-zgjedhor $\leftarrow$ Adj zgjedhor 'wyborczy') itd.

\section{prapa-}

prapagjuhor - 'tylnojęzykowy' (Adj prapa-gjuhor $\leftarrow$ Adj gjuhor 'językowy') $i$ prapavendosur - 'umiejscowiony $\mathrm{z}$ tyłu' (Adj $i$ prapa-vendosur $\leftarrow \operatorname{Adj} i$ vendosur 'umiejscowiony')

i prapambetur - 'zacofany' (Adj i prapa-mbetur $\leftarrow$ Adj i mbetur 'pozostały')

prapaveprues - 'działający wstecz' (Adj prapa-veprues $\leftarrow$ Adj veprues 'aktywny') prapaveshtrues - 'retrospektywny' (Adj prapa-veshtrues $\leftarrow$ Adj veshtrues 'obserwujący')

itd.

\section{kundër-}

kundërkimik - 'przeciwchemiczny' (Adj kundër-kimik $\leftarrow$ Adj kimik 'chemiczny') kundërligjor - 'przeciwprawny' (Adj kundër-ligjor $<$ Adj ligjor 'prawny') kundërbërthamor - 'przeciwjądrowy' (Adj kundër-bërthamor $<$ Adj bërthamor 'jądrowy')

kundërnjerëzor - 'przeciwko ludzkości' (Adj kundër-njerëzor $<$ Adj njerëzor 'ludzki') $i$ kunderligjshëm - 'przeciwko prawu' (Adj i kundër-ligjshëm $\leftarrow$ Adj $i$ ligjshëm 'prawny') itd.

stër-

i stërgjatë - 'długaśny’ (Adj i stër-gjatë $<$ Adj i gjatë 'długi’)

$i$ stërmadh - 'ogromny' (Adj $i$ stër-madh $\leftarrow$ Adj i madh 'duży')

i stërlashtë - 'prastary' (Adj i stër-lashtë $\leftarrow$ Adj i lashtë 'stary’)

i stërhollë - 'cieniutki' (Adj i stër-hollë $<$ Adj i hollë 'cienki')

itd.

${ }^{6}$ Participia zaliczane są w języku albańskim do klasy przymiotników na zasadzie charakterystyki formalno-składniowej. 


\section{ultra-}

ultramodern - 'ultranowoczesny' (Adj ultra-modern $<$ Adj modern 'nowoczesny') ultrahelmues - 'bardzo trujący' (Adj ultra-helmues $\leftarrow$ Adj helmues 'trujący') ultraviolet - 'ultrafioletowe' (Adj ultra-violet $\leftarrow$ Adj violet 'fioletowy') itd.

$m b i-$

mbinjerëzor - 'nadludzki' (Adj mbi-njerëzor $\leftarrow$ Adj njerëzor 'ludzki') mbitokësor - 'naziemny' (Adj mbi-tokësor $\leftarrow$ Adj tokësor 'ziemny') i mbinatyrshëm - 'nadnaturalny' (Adj $i$ mbi-natyrshëm $\leftarrow$ Adj $i$ natyrshëm 'naturalny')

i mbiujshëm - 'ponadwodny' (Adj i mbi-ujshëm $\leftarrow$ Adj i ujshëm 'wodny') itd.

\section{ndër-}

ndërkombëtar - 'międzynarodowy' (Adj ndër-kombëtar $\leftarrow$ Adj kombëtar 'narodowy')

ndërshtetëror - 'międzypaństwowy' (Adj ndër-shtetëror $<$ Adj shtetëror 'państwowy') ndërluftues - 'międzywojenny' (Adj ndër-luftues $\leftarrow$ Adj luftues 'wojenny') itd.

$$
\text { i- (in-, im-) }
$$

imoral - 'niemoralny' (Adj i-moral $\leftarrow$ Adj moral 'moralny') inorganik - 'nieorganiczny' (Adj in-organik $<$ Adj organik 'organiczny') itd.

super-

superstrukturor - 'superstrukturalny' (Adj super-strukturor $\leftarrow$ Adj strukturor 'strukturalny')

supermodern - 'supernowoczesny, bardzo nowoczesny' (Adj super-modern $\leftarrow$ Adj modern 'nowoczesny') itd.

\section{lart-}

i lartpërmendur - 'wyżej (wcześniej) wspomniany' (Adj i lart-përmendur $\leftarrow$ Adj i përmendur 'wspomniany')

i lartshënuar - 'wyżej zaznaczony' (Adj i lart-shënuar $<$ Adj i shënuar 'zaznaczony') itd. 


\section{poshtë-}

i poshtëpërmendur - 'niżej wymienione' (Adj i poshtë-përmendur $\leftarrow$ Adj i përmendur 'wspomniany')

$i$ poshtëshënuar - 'niżej zaznaczone' (Adj $i$ poshtë-shenuar $\leftarrow$ Adj $i$ shenuar 'zaznaczony')

itd.

\section{sipër-}

i sipërtreguar - 'wyżej wskazany' (Adj i sipër-treguar $<$ Adj i treguar 'wskazany') $i$ sipërshënuar - 'wyżej zaznaczony' (Adj $i$ sipër- shënuar $\leftarrow$ Adj $i$ shënuar 'zaznaczony')

$i$ sipërmendur - 'wyżej wspomniany' (Adj i sipër-mendur $\leftarrow$ Adj $i$ mendur 'wspomniany')

i sipërthënё - 'wyżej powiedziany' (Adj $i$ sipër-thënë $\leftarrow$ Adj $i$ thënë 'powiedziany') $i$ sipërvendosur - 'wyżej umiejscowiony' (Adj $i$ sipër-vendosurr $\leftarrow$ Adj $i$ vendosur 'umiejscowiony')

itd.

\section{drejt-}

drejtshkrimor - 'pisowniowy' (Adj drejt-shkrimor $<$ Adj shkrimor 'piśmienniczy') drejtshqiptimor - 'poprawnie wymawiany' (Adj drejt-shqiptimor $\leftarrow$ Adj shqiptimor 'wymawiany')

drejtvizor - 'prostoliniowy' (Adj drejt-vizor $\leftarrow$ Adj vizor 'liniowy') drejtkëndor - 'prostokątny' (Adj drejt-këndor $<$ Adj këndor 'kątowy') itd.

\section{gjithe्e-}

i gjithëfuqishëm - 'wszechmocny' (Adj i gjithë-fuqishëm $\leftarrow$ Adj $i$ fuqishëm 'mocny')

i gjithëllojshëm - 'wszelkiego rodzaju' (Adj i gjithë-llojshëm $\leftarrow$ Adj i llojshëm 'różnego typu')

i gjithëanshëm - 'wszechstronny' (Adj i gjithë-anshëm $\leftarrow$ Adj $i$ anshëm 'stronniczy')

i gjithëpushtetshëm - 'wszechmocny, mający całą władzę' (Adj i gjithë-pushtetshëm $\leftarrow$ Adj i pushtetshëm 'potężny')

gjithëkombëtar - 'związany z całym krajem' (Adj gjithë-kombëtar $\leftarrow$ Adj kombëtar 'narodowy')

itd. 


\section{gjysmë-}

gjysmëkilësh - 'półkilogramowy' (Adj gjysmë-kilësh $\leftarrow$ Adj kilësh 'kilogramowy') gjysmëgjallë - 'półżywy' (Adj gjysmë-gjallë $<$ Adj gjallë ‘żywy’)

gjysmëshekullor - 'półwiekowy' (Adj gjysmë-shekullor $\leftarrow$ Adj shekullor 'wiekowy') gjysmëanalfabet - 'półanalfabetyczny' (Adj gjysmë-analfabet $\leftarrow$ Adj analfabet 'analfabetyczny')

gjysmëzyrtar - 'półoficjalny' (Adj gjysmë-zyrtar $<$ Adj zyrtar 'oficjalny') gjysmëbujqësor - 'półrolny' (Adj gjysmë-bujqësor $<$ Adj bujqësor 'rolny') itd.

\section{jashtë-}

i jashtëzakonshëm - 'nadzwyczajny' (Adj i jashtë-zakonshëm $\leftarrow$ Adj i zakonshëm 'zwyczajny')

jashtëtokësor - 'pozaziemski' (Adj jashtë-tokësor $<$ Adj tokësor 'ziemski') jashtëshkollor - 'pozaszkolny' (Adj jashtë-shkollor $\leftarrow$ Adj shkollor 'szkolny') jashtëklasor - 'pozaklasowy' (Adj jashtë-klasor $\leftarrow$ Adj klasor 'klasowy') i jashtënatyrshëm - 'nienaturalny' (Adj i jashtë-natyrshëm $\leftarrow$ Adj i natyrshëm 'naturalny')

jashtëligjor - 'będący poza prawem' (Adj jashtë-ligjor $<$ Adj ligjor 'prawny') jashtëgjuhësor - 'pozajęzykowy' (Adj jashtë-gjuhësor $<$ Adj gjuhësor 'językowy') itd.

plot-

i plotfuqishëm - 'wszechmocny' (Adj i plot-fuqishëm $<$ Adj i fuqishëm 'mocny, silny') i plotpjesëtueshëm - 'podzielny bez reszty' (Adj i plot-pjesëtueshëm $\leftarrow$ Adj i pjesëtueshëm 'podzielny')

i plotpushtetshëm -'wszechwładny' (Adj i plot-pushtetshëm $\leftarrow$ Adj i pushtetshëm 'wszechwładny')

i plotvlerëshëm - 'pełnowartościowy' (Adj i plot-vlerëshëm $\leftarrow$ Adj $i$ vlerëshëm 'wartościowy')

itd.

shumë-

shumëfazesh - 'wielofazowy' (Adj shumë-fazesh $<$ Adj fazesh 'fazowy')

shumëditor - 'wielodniowy' (Adj shumë-ditor $\leftarrow$ Adj ditor 'dzienny')

i shumëdashur - 'umiłowany' (Adj $i$ shumë-dashur $\leftarrow$ Adj $i$ dashur 'kochany') shumëmilionesh - 'wielomilionowy' (Adj shumë-milionesh $\leftarrow$ Adj milionesh 'milionowy') 
shumëgjymtyresh - 'wielopodmiotowy' (Adj shumë-gjymtyresh $\leftarrow$ Adj gjymtyresh 'podmiotowy')

i shumëngjyrshëm - 'wielokolorowy' (Adj i shumë-ngjyrshëm $<$ Adj i ngjyrshëm 'kolorowy')

itd.

\section{vetë-}

vetëkritik - 'samokrytyczny' (Adj vetë-kritik $\leftarrow$ Adj kritik 'krytyczny')

vetëdashës - 'kochający siebie, egoistyczny' (Adj vetë-dashës $\leftarrow$ Adj dashës

'kochający')

i vetëdijshëm - 'samoświadomy' (Adj $i$ vetë-dijshëm $<$ Adj $i$ dijshëm 'świadomy') vetëmohues - 'przeczący sobie' (Adj vetë-mohues $\leftarrow$ Adj mohues 'przeczący') vetëmbrojtës - 'chroniący siebie' (Adj vetë-mbrojtës $\leftarrow$ Adj mbrojtës 'ochronny') $i$ vetëkënaqur - 'zadowolony z siebie' (Adj $i$ vetë-kënaqur $\leftarrow$ Adj $i$ kënaqur 'zadowolony')

itd.

Uwzględnić należy jeszcze mniej produktywne filo-, gjeo-, hidro-, mono-, poli-, pseudo - afiksoidy (dokł. prefiksoidy) pochodzenia obcego.

Klasa albańskich przymiotnikowych derywatów prefiksalnych jest bardzo rozbudowana pod względem ilości prefiksów. Naturalnie, jedne prefiksy wykazują się dużą produktywnością, podczas gdy inne są już prawie w ogóle nieproduktywne. Proces derywacji polega wyłącznie na afiksacji, brak tu redukcji i alternacji $\mathrm{w}$ temacie. W procesie derywacji tej grupy derywatów brak także rodzajnika prepozytywnego jako morfemu gramatycznego w funkcji słowotwórczej. Przymiotniki derywowane przy pomocy prefiksów są już motywowane przez tematy przymiotnikowe, brak więc zmiany paradygmatu jednostki leksykalnej.

\section{C - paradygmatyczne}

derywowane od tematów czasownikowych w formie pjesore?

i afruar - 'bliski, przystępny' (Adj [i] afruar $\leftarrow \mathrm{V}_{\mathrm{Pjes}}$ afruar - forma pjesore od czasownika afroj 'zbliżać, przybliżać')

$i$ besuar - 'godny zaufania' (Adj [i] besuar $\leftarrow \mathrm{V}_{\text {Pjes }}$ besuar 'godny zaufania') $i$ dredhur - 'zakrzywiony, powykręcany' (Adj [i] dredhur $\leftarrow \mathrm{V}_{\text {Pjes }}$ dredhur 'zakrzywiony')

7 Pjesorja imiesłów czynny czasu przeszłego, np. nisur $\leftarrow$ nis. 
i edukuar - 'wyedukowany' (Adj [i] edukuar $\leftarrow \mathrm{V}_{\text {pjes }}$ edukuar 'wyedukowany') $i$ hapur - 'otwarty' (Adj [i] hapur $\leftarrow \mathrm{V}_{\text {pjes }}$ hapur 'otwarty') i nisur - 'rozpoczety' (Adj [i] nisur $\leftarrow \mathrm{V}_{\mathrm{P} \text { Pes }}$ nisur 'rozpoczęty') i përdorur - 'używany' (Adj [i] përdorur $\leftarrow \mathrm{V}_{\mathrm{Pjes}}$ përdorur 'używany') $i$ vrarë - 'zamordowany' (Adj [i] vrarë $\leftarrow \mathrm{V}_{\text {Pjes }}$ vrarë 'zamordowany') i zënё - 'zajęty' (Adj [i] zënё $\leftarrow \mathrm{V}_{\text {Pjes }}$ zënё 'zajęty') i këputur - 'skonany' (Adj [i] këputur $\leftarrow \mathrm{V}_{\text {Pjes }}$ këputur 'skonany') i rrahur - 'bity, rozbity' (Adj [i] rrahur $\leftarrow \mathrm{V}_{\text {Pjes }}$ rrahur 'bity, rozbity') $i$ thinjur - 'sędziwy' (Adj [i] thinjur $\leftarrow \mathrm{V}_{\text {Pjes }}$ thinjur 'sędziwy') $i$ vendosur - 'zdecydowany' (Adj [i] vendosur $\leftarrow \mathrm{V}_{\text {pjes }}$ vendosur 'zdecydowany') i lartësuar - 'wyniosły, egzaltowany, patetyczny' (Adj [i] lartësuar $\leftarrow \mathrm{V}_{\mathrm{Pjes}}$ lartësuar 'wyniosły, egzaltowany, patetyczny') itd.

a. derywowane od tematów rzeczownikowych: ar - 'żółty, jasny, złoty' (Adj ar- $[\varnothing] \leftarrow \mathrm{N}$ ar 'złoto') argjend - 'biały, srebrzysty' (Adj argjend-[ø] $\leftarrow \mathrm{N}$ argjend 'srebro') aventurier - 'awanturniczy' (Adj aventurier- $[\varnothing] \leftarrow \mathrm{N}$ aventurier 'awanturnik')

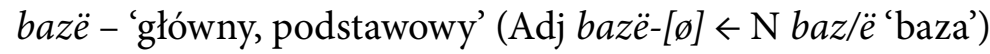
farës - 'ziarnisty' (Adj farës- $[\varnothing] \leftarrow \mathrm{N}$ farës 'ziarno') flori - 'ze złota, mający dobre cechy - cudowny, wartościowy' (Adj flori-[ø] $\leftarrow$ $\mathrm{N}$ flori 'złotko')

flutur - 'mający wygląd, kształt motyla lub ruszający się jak motyl' (Adj flutur-[ø] $\mathrm{N}$ flutur 'motyl') furtunë - 'szybki, zręczny' (Adj furtunë- $[\varnothing] \leftarrow \mathrm{N}$ furtunë 'burza') çallë = i papjekur, i pabërë - 'niedopieczony, niedojrzały (głównie o owocach)', np. fik çallë 'niedopieczona figa' (Adj çallë- $[\varnothing] \leftarrow \mathrm{N}$ çallë 'surowizna') kërce - 'zamrożony' (Adj kërce-[ø] $\leftarrow \mathrm{N}$ kërce 'mrożonka') lëkurë - 'o mięsie - słabe, marne' (Adj lëkurë-[ø] $\leftarrow$ N lëkur/ë 'skóra') mistrec - 'mizerne, mierne (o zwierzętach i roślinach - nierozwinięte)' (Adj mistrec- $[\varnothing] \leftarrow \mathrm{N}$ mistrec 'miernota') letrar - 'literacki' (Adj letrar- $[\varnothing] \leftarrow \mathrm{N}$ letrar, $-i$ 'literat') itd.

b. derywaty motywowane przez więcej niż jeden temat słowotwórczy

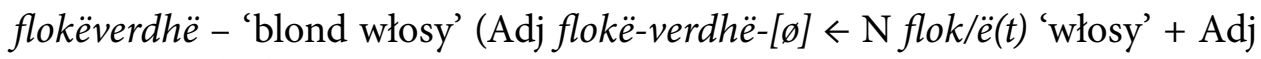
i verdhë 'żółty') 
gojëndyrë - 'szyderczy' (Adj gojë-ndyrë-[ø] $\leftarrow \mathrm{N}$ goj/ë, -a 'usta' + Adj i ndyrë 'żółty')

sylesh - 'łatwowierny' (Adj sy-lesh-[ø] $\leftarrow \mathrm{N} s y,-t e \ddot{~ ' o c z y ' ~+~ N ~ l e s h, ~}-i$ 'wełna') itd.

Do tej podklasy można zaliczyć także specyficzne derywaty utworzone od dwóch takich samych tematów rzeczownikowych w liczbie mnogiej i formie określonej:

pika-pika - 'kropkowany' (Adj pika-pika-[ø] N pika 'krople' + N pika 'krople') ngjyra-ngjyra - 'różnokolorowy' (Adj ngjyra-ngjyra-[ø] $\leftarrow \mathrm{N}$ ngjyra 'barwy' + $\mathrm{N}$ ngjyra 'barwy')

cirka-cirka - 'kropelkowy' (Adj cirka-cirka-[ø] $\leftarrow \mathrm{N}$ cirka 'krople' + N cirka 'krople')

gropa-gropa - 'bardzo dziurawy' (Adj gropa-gropa-[ø] $\leftarrow \mathrm{N}$ gropa 'dziury' + $\mathrm{N}$ gropa 'dziury')

itd.

Podwojenie tematu nie tylko zmienia paradygmat na przymiotnikowy, lecz także ma za zadanie wzmocnić znaczenie przymiotnika.

W ramach klasy derywatów paradygmatycznych wyszczególniono derywaty utworzone od tematów czasownikowych w formie pjesore oraz od rzeczowników, a także derywaty motywowane przez więcej niż jeden temat słowotwórczy. Stosunkowo najliczniejsze są te derywowane od tematów czasownikowych w formie pjesore. W klasie derywatów wyłącznie paradygmatycznych nie wyodrębniamy segmentu afiksalnego, brak tu także redukcji i alternacji tematowych. W najliczniejszej podgrupie derywatów paradygmatycznych utworzonych od tematów czasownikowych $\mathrm{w}$ formie pjesore zmiana paradygmatu ma powierzchniowy wykładnik w postaci rodzajnika prepozytywnego ( $i$ dla rodzaju męskiego, $e$ dla rodzaju żeńskiego, të dla rodzaju nijakiego i liczby mnogiej wszystkich rodzajów). W podgrupie derywatów utworzonych od tematów rzeczownikowych brak powierzchniowego wykładnika paradygmatycznego w postaci rodzajnika prepozytywnego. Forma derywatu jest taka sama jak forma tematu motywującego derywat. Zmienia się przynależność klasy gramatycznej nowo powstałej jednostki leksykalnej. W podgrupie c. w procesie derywacji nieprzymiotnikowy paradygmat jednego bądź dwu tematów motywujących derywat przechodzi w paradygmat przymiotnikowy nowo powstałego derywatu. Tematy w derywacie tego typu mogą być połączone za pomocą myślnika i mieć dwa akcenty (np. pika-pika 'kropkowany') albo tworzyć jeden wyraz prozodyczny (np. sylesh 'łatwowierny'). 


\section{D - prefiksalno-paradygmatyczne}

\section{$p a-$}

i pakripë - '1. niesłony, 2. absurdalny', np. shaka e pakripë - 'absurdalny żart' (Adj [i] pa-kripë $\leftarrow \mathrm{N} k r i p \ddot{e},-a$ 'sól') i payndyrë - 'beztłuszczowy' (Adj [i] pa-yndyrë $\leftarrow \mathrm{N}$ yndyr/ë, -a 'olej') $i$ painteres - 'bezinteresowny' (Adj [i] pa-interes $\leftarrow \mathrm{N}$ interes, $-i$ 'interes') i pavlerë - 'bezwartościowy' (Adj [i] pa-vlerë $\leftarrow \mathrm{N}$ vler/ë, - a 'wartość') itd.

Grupa derywatów ograniczona do połączenia prefiksu pa- i tematu rzeczownikowego. Formalnym powierzchniowym wykładnikiem zmiany paradygmatu jest rodzajnik prepozytywny.

\section{E - sufiksalne}

$-(\ddot{e}) s$

mbytës - 'duszący' (Adj mbyt-ës[ø] $\leftarrow \mathrm{V}$ mbyt 'dusić')

ngjitës - 'łączący' (Adj ngjit-ës[ø] V ngjit 'łączyć')

mbrojtës - 'ochronny, obronny' (Adj mbrojt-ës[ø] $\leftarrow \mathrm{N}$ mbrojt/je 'ochrona')

vajës - 'płaczliwy' (Adj vaj-ës $[\varnothing] \leftarrow \mathrm{V}$ vaj 'płakać')

ujës - 'wodnisty' (Adj ujë-s[ø]

mbushës - 'napełniająca' (Adj mbush-ës $[\varnothing] \leftarrow \mathrm{V}$ mbush 'napełniać')

mirëbërës - 'dobroczynny' (Adj mirë-bërë-s $[\varnothing] \leftarrow A d v$ mirë $\mathrm{V}_{\text {pjes }}$ bërë 'robiący') itd.

$-(\ddot{e}) s h$

ngjyrësh - 'kolorowy' (Adj ngjyr-ësh $[\varnothing] \leftarrow \mathrm{N} n g j y r / \ddot{e},-a$ 'barwa, kolor')

muajsh - 'miesięczny' (Adj muaj-sh $[\varnothing] \leftarrow \mathrm{N}$ muaj, -i 'miesiąc')

itd.

-ues (-yes)

manipulues - 'manipulacyjny' (Adj manipul-ues $[\varnothing] \leftarrow \mathrm{V}$ manipul/oj 'manipulować')

alarmues - 'alarmujący' (Adj alarm-ues[ø] $\leftarrow \mathrm{V}$ alarm/oj 'alarmować')

gjallërues - 'ożywczy' (Adj gjallër-ues[ø] $\leftarrow \mathrm{V}$ gjallër/oj 'ożywiać)

dyshues - 'podejrzliwy' (Adj dysh-ues $[\varnothing] \leftarrow \mathrm{V} d y s h / o j$ 'podejrzewać')

protestues - 'protestacyjny' (Adj protest-ues $[\varnothing] \leftarrow \mathrm{V}$ protest/oj 'protestować) 
dezinfektues - 'dezynfekujący' (Adj dezynfekt-ues[ø] $\leftarrow \mathrm{V}$ dezynfekt/oj 'dezynfekować)

shkëlqyes - 'błyszczący' (Adj shkëlq-yes[ø] $<\mathrm{V}$ shkëlq/ej 'błyszczeć')

ngarkues - 'załadunkowy' (Adj ngark-ues $[\varnothing] \leftarrow \mathrm{V}$ ngark/oj 'łądować')

shpëtues - 'ratunkowy' (Adj shpët-ues $[\varnothing] \leftarrow \mathrm{V}$ shpët/oj 'ratować')

ekzekutues - 'egzekucyjny' (Adj mbyt-ues $[\varnothing] \leftarrow \mathrm{V}$ ekzekut/oj 'dokonywać egzekucji')

parashikues - 'przewidujący' (Adj parashik-ues $[\varnothing] \leftarrow \mathrm{V}$ parashik/oj 'przewidywać) itd.

$-a r$

arbitrar - 'arbitralny' (Adj arbitr-ar $[\varnothing] \leqslant \mathrm{N}$ arbit/ër, -ri 'arbiter')

detar - 'morski' (Adj det-ar $[\varnothing] \leftarrow \mathrm{N}$ det, $-i$ 'morze')

bregdetar - 'przybrzeżny' (Adj bregdet-ar $[\varnothing] \leftarrow \mathrm{N}$ bregdet, $-i$ 'brzeg morza')

planetar - 'planetarny' (Adj planet-ar $[\varnothing] \leftarrow \mathrm{N}$ planet, $-i$ 'planeta')

mesjetar - 'średniowieczny' (Adj mesjet-ar $[\varnothing] \leftarrow \mathrm{N}$ mesjetë, $-a$ 'średniowiecze')

opozitar - 'opozycyjny' (Adj opozit-ar $[\varnothing] \leftarrow \mathrm{N}$ opozitë, -a 'opozycja')

elementar - 'elementarny' (Adj element-ar $[\varnothing] \leftarrow \mathrm{N}$ element, $-i$ 'element')

itd.

$-\operatorname{tar}$

kombëtar - 'narodowy' (Adj komb-ë-tar $[ø] \leftarrow \mathrm{N} k o m b,-i$ 'naród') ${ }^{8}$

mesdhetar - 'śródziemnomorski' (Adj mesdhe-tar $[\varnothing] \leftarrow \mathrm{N}$ Mesdhe, -u 'Morze Śródziemne')

përfundimtar - 'ostateczny' (Adj përfundim-tar $[\varnothing] \leqslant \mathrm{N}$ përfundim, -i 'kończenie') vendimtar - 'decydujący' (Adj vendim-tar $[\varnothing] \leftarrow \mathrm{N}$ vendim, $-i$ 'decyzja')

luftëtar - 'wojskowy' (Adj luftë-tar $[\varnothing] \leftarrow \mathrm{N} l u f t e ̈, ~-a$ 'wojna')

itd.

$-o r$

gjymnastikor - 'gimnastyczny' (Adj gjymnastik-or $[\varnothing] \leftarrow \mathrm{N}$ gjymnastik/ë, $-a$ 'gimnastyka')

vendor - 'państwowy' (Adj vend-or $[\varnothing] \leftarrow \mathrm{N}$ vend, -i 'państwo')

lumor - 'rzeczny' (Adj lum-or $[\varnothing] \leftarrow \mathrm{N}$ lum/ë, -i 'rzeka')

ajror - 'powietrzny' (Adj ajr-or $[\varnothing] \leftarrow \mathrm{N}$ aj/ër, -i 'państwo')

${ }^{8} \mathrm{~W}$ tym przykładzie trudną grupę spółgłoskową rozbija głoska $\ddot{e}$. 
spitalor - 'szpitalny' (Adj spital-or $[\varnothing] \leftarrow \mathrm{N}$ spital, -i 'państwo')

armiqësor - 'wrogi' (Adj armiqes-or $[\varnothing] \leftarrow \mathrm{V}$ armiqës/oj 'być dla kogoś wrogiem')

foshnjor - 'niemowlęcy' (Adj foshnj-or $[\varnothing] \leftarrow \mathrm{N}$ foshnj/ë, - a 'niemowlę')

ujor - 'wodny' (Adj uj-or $[\varnothing] \leftarrow \mathrm{N} u j / \ddot{e},-i$ 'woda')

malor - 'górski' (Adj mal-or $[\varnothing] \leftarrow \mathrm{N}$ mal, $-i$ 'góra')

shkëmbor - 'skalisty' (Adj shkëmb-or $[\varnothing] \leftarrow \mathrm{N}$ shkëmb,-i 'skała')

diellor - 'słoneczny' (Adj diell-or $[\varnothing] \leftarrow \mathrm{N}$ djell, $-i$ 'słońce')

itd.

- tor

baritor - 'pasterski' (Adj bari-tor $[\varnothing] \leftarrow \mathrm{N}$ bari, -u 'pasterz')

leshtor - 'włochaty' (Adj bari-tor $[\varnothing] \leftarrow \mathrm{N}$ lesh, $-i$ 'sierść)

itd.

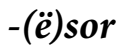

drusor - 'drewniany' (Adj dru-sor $[\varnothing] \leftarrow \mathrm{N} d r u$, -ri 'drewno')

mjekësor - 'lekarski' (Adj mjek-ësor $[\varnothing] \leftarrow \mathrm{N}$ mjek/ë, -u 'lekarz')

paqësor - 'pokojowy' (Adj paq-ësor $[\varnothing] \leftarrow \mathrm{N}$ paq/e, -ja 'pokój')

jetësor - 'życiowy' (Adj jet-ësor $[\varnothing] \leftarrow \mathrm{N}$ jet/ë, - a 'życie’)

tokësor - 'ziemski' (Adj tok-ësor $[\varnothing] \leftarrow \mathrm{N}$ tok/ë, -a 'ziemia')

gjyqësor - 'sądowy' (Adj gjyq-ësor $[\varnothing] \leftarrow \mathrm{N}$ gjyq, - $i$ 'sąd')

itd.

$-(\ddot{e})$ ror

shtetëror - 'państwowy' (Adj shtet-ëror $[\varnothing] \leftarrow \mathrm{N}$ shtet, -i 'państwo')

botëror - 'światowy' (Adj bot-ëror $[\varnothing] \leftarrow \mathrm{N}$ bot, $-i$ 'świat')

shpirtëror - 'duchowy' (Adj shpirt-ëror $[\varnothing] \leftarrow \mathrm{N}$ shpirt, -i 'dusza')

itd.

-ak (warianty -acak, -arak, -alak, -atak, -anjak)

luftarak - 'wojenny' (Adj luft-arak [ø] $\leftarrow \mathrm{N}$ luftë, - a 'wojna')

ushtarak - 'wojskowy' (Adj ushtar-ak[ø] $\leftarrow \mathrm{N}$ ushtar, -i 'żołnierz')

vezak - 'jajowaty' (Adj vez-ak[ø] $\leftarrow \mathrm{N}$ vezë, -a 'jajko')

perandorak - 'carski' (Adj perandor-ak $[\varnothing] \leftarrow \mathrm{N}$ perandor, $-i$ 'wojna')

dimërak - 'zimowy' (Adj dimër-ak $[\varnothing] \leftarrow \mathrm{N} \operatorname{dim} / \ddot{e} r$, -ri 'zima')

zemërak - 'humorzasty' (Adj zemër-ak[ø] $\leftarrow \mathrm{N}$ zem/ër, -ra 'serce')

itd. 


\section{-osh}

bardhosh - 'bielutki' (Adj [ø] bardh-osh $\leftarrow$ Adj i bardhë 'biały')

bukurosh - 'piękniutki' (Adj [ø] bukur-osh $\leftarrow$ Adj i bukur 'piękny')

gjatosh - 'chudawy' (Adj [ø] gjat-osh $\leftarrow$ Adj i gjatë 'chudy')

ziosh - 'czarniawy' (Adj [ø] zi-osh $\leftarrow$ Adj $i z i$ 'czarny')

thartosh - 'kwaskowaty' (Adj [ø] thart-osh $\leftarrow$ Adj i thartë 'kwaśny')

itd.

\section{- ush}

bardhush - 'bielusieńki' (Adj [ø] bardh-ush $\leftarrow$ Adj i bardhë 'biały')

gjatush - 'chudziutki' (Adj [ø] bgjat-ush $\leftarrow$ Adj i gjatë 'chudy')

thatush - 'suchutki' (Adj [ø] that-ush $\leftarrow$ Adj i thatë 'suchy')

verdhush - ‘źółciusieńki' (Adj [ø] verdh-ush $\leftarrow$ Adj i verdhë ‘żółty’)

bukurush - 'piękniuśki' (Adj [ø] bukur-ush $\leftarrow$ Adj i bukur 'biały')

larush - 'barwny' (Adj [ø] lar-ush $\leftarrow$ Adj $i$ larë 'barwny')

itd.

W przykładach z sufiksami -ush $\mathrm{i}$-osh widoczna jest zmiana paradygmatu przez redukcję rodzajnika w procesie derywacji. Derywaty pozostają jednak $\mathrm{w}$ tej samej klasie gramatycznej co fundujące je tematy przymiotnikowe.

$\mathrm{Z}$ mniej produktywnych sufiksów należy wymienić:

-ac (ngelac, qelbac)

-an (shkodran, dibran, keqan, kuqan, kaleshan, zhelan)

-ik (fotografik, atomik, akademik, biografik, teorik, zoologjik)

-al (kontinental, frontal, eksperimental, embrional, personal)

-ual (gradual, tekstual)

-iv (edukativ, federativ, objektiv, subjektiv)

-ian (evropian, shekspirian, drakonian)

-anik (qelbanik, trashanik, thatanik)

-uk (bardhuk, laruk)

-esk (libresk, shkollaresk)

-oz (ambicioz, nervoz, luksoz, poroz)

-in (alpin, dalmatin)

-m (i epërm, i parmë)

-e (djemurishte, burrërishte, dhënderishte, grarishte, pleqërishte)

Oprócz wyrazów motywowanych, powstałych wyłącznie przez dodanie do tematu afiksu znajdującego się w postpozycji do tematu, do grupy derywatów 
sufiksalnych zaliczyć trzeba także te powstałe na skutek derywacji za pomocą rodzajnika i sufiksu. Wynikiem tego procesu jest powierzchniowy wykładnik zmiany paradygmatu jednostki leksykalnej w postaci rodzajnika prepozytywnego.

a. Rodzajnik $i, e+$ sufiks -shëm

Derywaty utworzone od tematów rzeczownikowych:

i dëmshëm - 'szkodliwy' (Adj [i] dëm-shëm $\leftarrow \mathrm{N}$ dëm, -i 'szkoda')

i famshëm - 'znany' (Adj [i] fam-shëm $\leftarrow \mathrm{N}$ fam/ë, -a 'sława')

$i$ ligjshëm - 'prawny' (Adj [i] ligj-shëm $\leftarrow \mathrm{N}$ ligj, - $i$ 'prawo')

i nevojshëm - 'potrzebny' (Adj [i] nevoj-shëm $\leftarrow \mathrm{N}$ nevoj/ë, -a 'potrzeba')

izakonshëm - 'zwykły, zwyczajny' (Adj [i] zakon-shëm $\leftarrow \mathrm{N}$ zakon, -i 'nawyk, zwyczaj') i bujshëm - 'sensacyjny, mający duży wydźwięk, wprowadzający zamieszanie'

(Adj [i] buj-shëm $\leftarrow \mathrm{N} b u j$, - a 'zamieszanie')

i ujshëm - 'wodnisty' (Adj [i] uj-shëm $\leftarrow \mathrm{N}$ uj/ë, $-i$ 'woda')

i lëngshëm - 'ciekły' (Adj [i] leng-shëm $\leftarrow \mathrm{N}$ leng, -u 'ciecz')

itd.

Derywaty utworzone od tematów czasownikowych:

i ndjeshëm - 'wrażliwy, uczuciowy' (Adj [i] ndje-shëm $\leftarrow \mathrm{V}_{\text {pjes }}$ ndje/rë 'czuć')

i djegshëm - 'palny' (Adj [i] djeg-shëm $\leftarrow \mathrm{V}_{\text {pjes }}$ djeg/ur'palić')

i falshëm - 'wybaczalny' (Adj [i] fal-shëm $\leftarrow \mathrm{V}_{\text {pjes }}$ fal/ur 'przebaczyć')

i shkëlqyeshëm - 'błyszczący' (Adj [i] -shëm $\leftarrow \mathrm{V}_{\text {pjes }}$ djeg/ur 'palić')

i ushqyeshëm - 'jadalny' (Adj [i] ushqye-shëm $\leftarrow \mathrm{V}_{\text {pjes }}$ ushqye/r 'jeść')

i mundshëm - 'możliwy' (Adj [i] mund-shëm $\leftarrow \mathrm{V}_{\text {pjes }}$ mund/ur 'móc')

i tretshëm - 'rozpuszczalny' (Adj [i] tret-shëm $\leftarrow \mathrm{V}_{\text {pjes }}$ tret/ur 'rozpuszczać)

$i$ kapshëm - 'dostępny' (Adj [i] kap-shëm $\leftarrow \mathrm{V}_{\text {pjes }}$ kap/ur 'chwycić')

i pijshëm - 'pitny' (Adj [i] pi-j-shëm $\leftarrow \mathrm{V} p i$ 'pić')

$i$ dijshëm - 'znany' (Adj [i] di-j-shëm $\leftarrow \mathrm{V}$ di 'znać')

i wiele innych.

Temat derywatów przymiotnikowych odczasownikowych utworzonych za pomocą sufiksu -shëm i rodzajnika, będącego także powierzchniowym wykładnikiem zmiany paradygmatu, jest tematem czasownika w niepełnej

9 W dwóch ostatnich przykładach wstawne -j-dodawane jest do tematów czasowników zakończonych na samogłoskę (klasa wyabstrahowana po raz pierwszy przez Konstantina Kristoforidhiego pod koniec XIX wieku [por. Memushaj 2003: 41-62]. 
formie imiesłowowej pjesoria, której pozbawia się jej charakterystycznej końcówki -r(ë) lub -ur.

Derywaty utworzone od tematów przysłówkowych (w tym wyrażeń przysłówkowych):

i brendshëm - 'wewnętrzny' (Adj [i] brend-shëm $\leftarrow$ Adv brend/a 'wewnątrz') $i$ djeshëm - 'wczorajszy' (Adj [i] dje-shëm $\leftarrow$ Adv dje 'wczoraj') $i$ domosdoshëm - 'konieczny' (Adj [i] domosdo-shëm $\leftarrow$ Adv domosdo 'koniecznie') i gatshëm - 'gotowy' (Adj [i] gat-shëm $\leftarrow$ Adv gat $/ i$ 'od razu') $i$ herëshëm - 'wczesny, dawny' (Adj [i] herë-shëm $<$ Adv herë 'raz, teraz') i mëparshëm - 'wcześniejszy' (Adj [i] mëpar-shëm $<$ Adv më parë ${ }^{10}$ 'wcześniej') i inne.

Albański sufiks -shëm jest najbardziej produktywny, jeżeli chodzi o tworzenie derywatów przymiotnikowych. Przy jego pomocy można utworzyć przymiotnik od prawie każdego tematu czasownikowego.

b. Rodzajnik prepozytywny $i, e+$ sufiks -ueshëm:

i avullueshëm - 'lotny' (Adj [i] avull-ueshëm $\leftarrow \mathrm{V}$ avull/oj 'parować')

$i$ çmueshëm - 'cenny' (Adj [i] çm-ueshëm $\leftarrow \mathrm{V}$ çm/oj 'cenić')

$i$ dëshirueshëm - 'pożądany' (Adj [i] dëshir-ueshëm $\leftarrow \mathrm{V}$ dëshir/oj 'cenić')

i mrekullueshëm - 'cudowny, wspaniały' (Adj [i] mrekull-ueshëm $\leftarrow$ V mrekull/

oj 'fascynować')

i shkrueshëm - 'pisany' (Adj [i] skr-ueshëm $\leftarrow$ V shkr/uaj 'pisać')

i gëzueshëm - 'wesoły' (Adj [i] gëz-ueshëm $\leftarrow$ V gëz/oj 'weselić, cieszyć')

$i$ imagjinueshëm - 'wyobrażalny' (Adj [i] imagjin-ueshëm $\leftarrow$ V imagjin/oj 'wyobrażać')

i lexueshëm - 'czytelny' (Adj [i] lex-ueshëm $\leftarrow$ V lex/oj 'cenić')

i wiele innych.

Z formalnego punktu widzenia derywaty tego typu tworzą przede wszystkim tematy czasownikowe zakończone na -o (lexo-j, dëgjo-j, gëzo-j, dëshiro-j). Sufiks -ueshëm przyjmują również derywaty, których temat czasownikowy kończy się na -ua (shkrua-j).

${ }^{10}$ Wyrażenie przysłówkowe më parë ‘wcześniej’ stanowi całość tematu motywującego nowy derywat. Przyimek më nie jest w tym przypadku prefiksem tworzącym nową jednostkę leksykalną. W procesie derywacji udział bierze rodzajnik prepozytywny, zmieniający paradygmat derywatu oraz sufiks -shëm. 
c. Rodzajnik $i, e+\operatorname{sufiks}-(\ddot{e}) t(\ddot{e})$

Derywaty utworzone od tematów rzeczownikowych:

i artë - 'złoty' (Adj [i] ar-të $\leftarrow \mathrm{N}$ ar, -i 'złoto')

i gurtë - 'kamienisty' (Adj [i] gur-të $\leftarrow$ N gur, -i 'złoto')

i drunjtë - 'drewniany' (Adj [i] drunj-të $<\mathrm{N} d r u n j$, -të 'drewno')

i florinjtë - 'kwiecisty' (Adj [i] florinj-të $<\mathrm{N}$ florinj, -të 'kwiaty') ${ }^{11}$

i greptë - 'haczykowaty' (Adj [i] grep-të $\leftarrow \mathrm{N}$ grep, -i 'haczyk')

i inne.

Derywaty utworzone od tematów przysłówkowych:

i afërt - 'bliski' (Adj [i] afër- $t \leftarrow$ Adv afër 'blisko')

i barabartë - 'równy' (Adj [i] barabar-të $\leftarrow$ Adv barabar 'równie')

$i$ kundërt - 'przeciwny' (Adj [i] kunder- $t \leftarrow$ Adv kunder 'przeciwko')

i largët - 'daleki, odległy' (Adj [i] larg-ët $\leftarrow$ Adv larg 'daleko')

$i$ shumtë - 'liczny' (Adj [i] shum-të $\leftarrow$ Adv shumë 'dużo')

i veçantë - 'szczególny' (Adj [i] veçan-të $\leftarrow$ Adv veçan 'szczególnie')

$i$ tepërt - 'zbyteczny, zbędny' (Adj [i] tepër- $t \leftarrow$ Adv tepër 'zbyt')

$i$ shpeshtë - 'częsty' (Adj [i] shpesh-të $\leftarrow$ Adv shpesh 'często')

i inne.

Derywaty utworzone od tematów czasownikowych:

$i$ hapët - 'otwarty' (Adj [i] hap-ët $\leftarrow \mathrm{V}$ hap 'otwierać')

ifshehtë - 'schowany' (Adj [i] fsheh-të $\leftarrow \mathrm{V}$ fsheh 'chować')

$i$ ulët - 'niski' (Adj [i] ul-ët $\leftarrow \mathrm{V} u l$ 'obniżać')

d. Rodzajnik prepozytywny $i, e+\operatorname{sufiks~}-(\ddot{e}) m(\ddot{e})$ :

$i$ andejmë - $i$ andejshëm - 'tamtejszy' (Adj [i] andej-më $\leftarrow$ Adv andej 'tam')

i jashtëm - 'zewnętrzny' (Adj [i] jasht-ëm $\leftarrow$ Adv jasht 'na zewnątrz')

i fisëm - 'rodowy, plemienny' (Adj [i] fis-ëm $<\mathrm{N}$ fis, -i 'ród, plemię')

$i$ këtejmë - 'tutejszy' (Adj [i] këtej-më $\leftarrow$ Adv këtej 'tutaj')

i mesëm - 'środkowy, średni' (Adj [i] mes-ëm $<\mathrm{N}$ mes 'środek')

i mësipërm - 'powyższy' (Adj [i] mësipër-më $\leftarrow$ Adv mësipër 'powyżej')

$i$ sotëm - 'dzisiejszy' (Adj [i] sot-ëm $\leftarrow$ Adv sot 'tam')

itd.

11 Kilka derywatów tworzy się za pomocą tematu 1. mn., np. i drunjtë 'drewniany', i florinjtë 'kwiecisty'. 


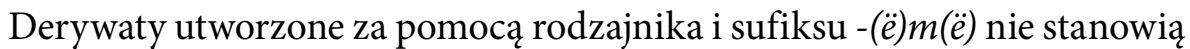
w leksyce albańskiej licznej grupy. Tworzone są głównie od tematów przysłówkowych, choć zdarzają się i tematy rzeczownikowe, np. fis 'plemię', mes 'środek'.

e. Rodzajnik prepozytywny $i, e+$ sufiks $-\ddot{e}$ :

$i$ drejtë - 'prosty, szczery, otwarty' (Adj [i] drejt-ë $\leftarrow$ Adv drejt 'prosto')

i fortë - 'silny' (Adj [i] fort- $\ddot{e}<\mathrm{Adv}$ fort 'silnie')

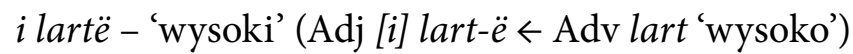

$i$ kotë - 'daremny, bezużyteczny' (Adj [i] kot-ë $\leftarrow$ Adv kot 'daremnie')

i mjaftë - 'wystarczający' (Adj [i] mjaft-ë $\leftarrow$ Adv mjaft 'wystarczająco')

i shpejtë - 'szybki' (Adj [i] shpejt-ë $\leftarrow$ Adv shpejt 'szybko')

$i$ vërtetë - 'prawdziwy' (Adj [i] vërtet-ë $\leftarrow$ Adv vërtet 'prawdziwie')

itd.

Derywaty przymiotnikowe powstałe w wyniku dodania rodzajnika i sufiksu

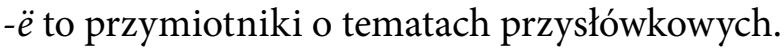

W ramach podsumowania rozważań dotyczących całej grupy derywatów sufiksalnych należy przede wszystkim zwrócić uwagę na obecność wykładnika paradygmatycznego w tego typu nowo powstałych jednostkach leksykalnych. Może on nie mieć powierzchniowej reprezentacji (np. ngji-tës[ø]), może też pojawić się w formie rodzajnika prepozytywnego, który w procesie derywacyjnym tej grupy derywatów stanowi czynnik słowotwórczy, tak samo jak przyłączany do danego tematu sufiks. Stosunkowo duża liczba derywatów przymiotnikowych tworzonych za pomocą sufiksu i dodania morfemu gramatycznego w postaci rodzajnika prepozytywnego wskazuje na to, że jest to najbardziej produktywny sposób tworzenia derywatów przymiotnikowych w języku albańskim. Nie ma na to wpływu niewielka liczba sufiksów biorących udział w tym sposobie

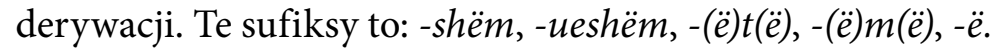

\section{F - prefiksalno-sufiksalne}

Derywaty przymiotnikowe utworzone według schematu rodzajnik + prefiks + temat + sufiks:

i përbashkët - 'wspólny' (Adj [i] për-bashkë-t $\leftarrow$ Adv bashkë 'razem')

i përfushtë - 'równy, płaski płytki' (Adj [i] për-fush-të $\leftarrow \mathrm{N}$ fush/ë, -a 'pole')

i përciptë - 'powierzchowny' (Adj [i] për-cip-të $\leftarrow \mathrm{N}$ cip/ë, - $a$ 'warstwa pokrywająca, skórka')

i përbotshëm - 'uniwersalny' (Adj [i] për-bot-shëm $\leftarrow \mathrm{N}$ bot, $-i$ 'świat') 
i përkohshëm - 'tymczasowy' (Adj [i] për-koh-shëm $\leftarrow \mathrm{N} k o h / \ddot{e},-a$ 'czas')

i përgjitshëm - 'ogólny' (Adj [i] për-gjithë-shëm $<$ Adv gjithë 'cały')

itd.

Ten sposób tworzenia derywatów przymiotnikowych w języku albańskim jest mało produktywny. Biorą w nim udział wyłącznie prefiks për $r$, sufiksy -t(ë), -shëm oraz rodzajnik. Tematami słowotwórczymi przy tego typu derywacji są tematy rzeczownikowe, zaimkowe i odprzysłówkowe.

\section{G - redukcyjno-interfiksalne}

elektromagnetik - 'elektromagnetyczny' (Adj elektr-o-magnetik $[\varnothing] \leftarrow$ Adj elektrik + Adj magnetik)

Derywaty $\mathrm{z}$ redukcją $\mathrm{w}$ temacie występują w języku albańskim rzadko. Zwykle są to internacjonalizmy, jak np. formacje z prefiksoidem elektro- derywowanym od przymiotnika elektrik.

Aby podsumować powyższe rozważania dotyczące klas formalnych albańskich derywatów przymiotnikowych, należałoby zwrócić uwagę na brak alternacji tematowych funkcjonujących jako środek słowotwórczy w procesie derywacji. Jeśli chodzi o przykłady, co do których zachodziło podejrzenie, że zawierają alternacje głosek tematowych, to po analizie okazało się jednak, że zostały derywowane od tematów, w których alternacja głosek wystąpiła już na wcześniejszym etapie derywacji. To niewątpliwie wynik tego, że struktura zarówno tematów rzeczownikowych, jak i - tym bardziej - przymiotnikowych, jest na ogół stabilna i nie dochodzi w niej do alternacji tematowych, przynajmniej w procesie tworzenia derywatów przymiotnikowych ${ }^{12}$. Dlatego też redukcji w temacie nie można uznać za powszechny proces derywacyjny tworzący nowe przymiotnikowe jednostki leksykalne w języku albańskim.

Stosunkowo najpowszechniejszymi strukturami formalnymi albańskich derywatów przymiotnikowych są struktury paradygmatyczne - mowa tu w szczególności o tworzeniu derywatów przymiotnikowych od tematów czasownikowych w formie pjesore - oraz struktury sufiksalne, w których na szczególną uwagę z punktu widzenia częstości występowania zasługuje struktura formalna derywatów powstałych w wyniku dodania do tematu sufiksu i morfemu gramatycznego w postaci rodzajnika prepozytywnego. Formę imiesłowową pjesore możemy utworzyć od

12 Alternacje w tematach rzeczownikowych są częste głównie w zmianie paradygmatu liczby [por. Sawicka, Mindak 1993: 32]. Także w tematach czasownikowych - zarówno pochodzenia praindoeuropejskiego, jak i praalbańskiego - alternacje tematowe występują obficie. 
praktycznie każdego czasownika - zarówno przechodniego, jak i nieprzechodniego. Z kolei po przyjęciu rodzajnika prepozytywnego forma ta wchodzi w paradygmat klasy przymiotnika. Klas derywatów: prozodycznej, postfiksalnej, prefiksalno-postfiksalnej, interfiksalno-paradygmatycznej, postfiksalno-paradygmatycznej, prefiksalno-postfiksalno-paradygmatycznej, interfiksalno-sufiksalnej, alternacyjno-paradygmatycznej, alternacyjno-afiksalnej, redukcyjno-paradygmatycznej, redukcyjno-afiksalnej, redukcyjno-alternacyjno-paradygmatycznej i redukcyjno-alternacyjno-afiksalnej w materiale albańskich derywatów przymiotnikowych nie stwierdzono. Z pewnością część z tych klas ma swoje wykładniki w innych klasach gramatycznych języka albańskiego, część też nie występuje w ogóle, jednak do formułowania wniosków w tym zakresie niezbędne byłoby przeprowadzenie odrębnego badania. Wyszczególniono za to, w porównaniu z modelem wzorcowym, klasę derywatów redukcyjno-interfiksalnych.

\section{Wykaz skrótów i symboli stosowanych w pracy}

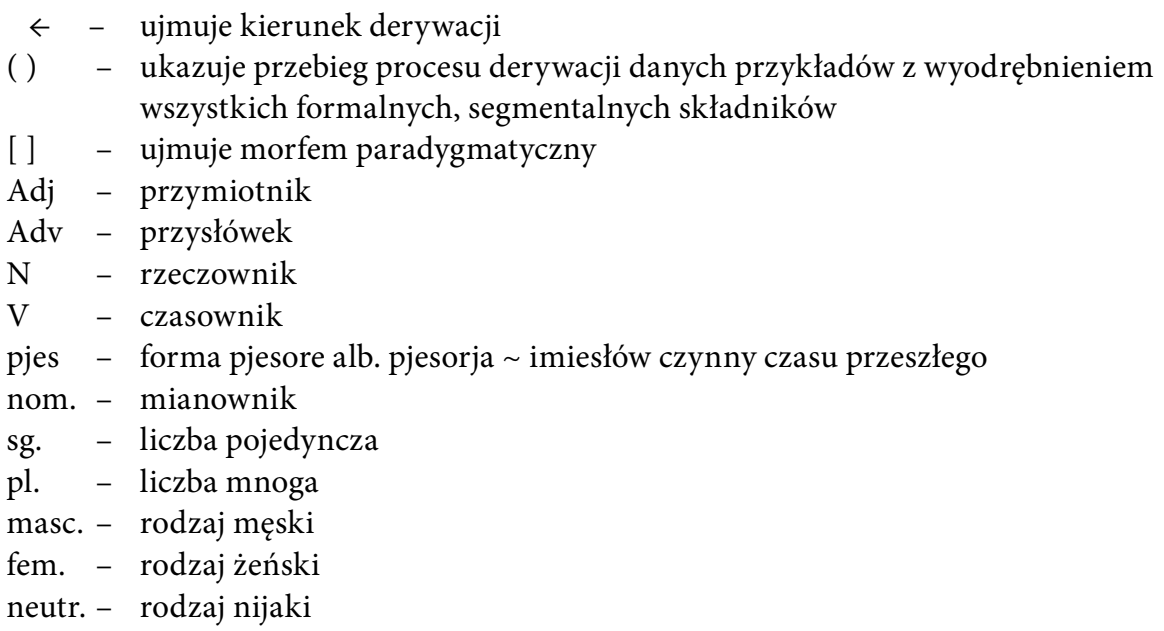

\section{Bibliografia}

Beci B., 2001, Gramatika e gjuhës shqipe për të gjithë, Prishtinë.

Cipo K., 1972, Studime mbi leksikun dhe mbi formimin e fjalëve në gjuhën shqipe I, Tiranë, s. 61-66.

Çeliku M. (red), 2007, Gramatika praktike e gjuhës shqipe, Tiranë.

Demiraj Sh. (red.), 1976, Gramatika e gjuhës shqipe, vëllimi I morfologjia, wyd. 2, Tiranë 1995.

Encyklopedia językoznawstwa ogólnego, Polański K. (red.), Wrocław 1999. 
Fjalor i Gjuhës Shqipe, Thomai J. (red.), Akademia e Shkencave e Shqipërisë, Instituti i Gjuhësisë dhe i Letërsisë, Tiranë 2006.

Fjalor i Shqipës së Sotmë, Akademia e Shkencave e RPS të Shqipërisë, Instituti i Gjuhësisë dhe Letërsisë, Tiranë 1984.

Honowska M, 1967, Zarys klasyfikacji polskich derywatów, Wrocław.

Karasiński A., 2009, Albańskie derywaty przymiotnikowe z prefiksem pa-, [w:] Linguistica Copernicana 2, Toruń, s. 315-326.

Karasiński A., 2010, Albańskie odczasownikowe derywaty przymiotnikowe [w:] „Slavia Meridionalis" 10, Warszawa, s. 125-134.

Kostallari A., 1972, Mbi disa veçori të fjalës së përbërë në gjuhën shqipe, [w:] Studime mbi leksikun dhe mbi formimin e fjalëve në gjuhën shqipe I, Tiranë, s. 141-147.

Maldjieva V., 2007, Funkcje derywatów w tekście (propozycja modelu analizy i opisu), [w:] V. Maldjieva i Z. Rudnik-Karwatowa (red.), Słowotwórstwo i tekst, Warszawa, s. 120-129.

Maldjieva V., 2009, Gramatyka konfrontatywna bułgarsko-polska, Słowotwórstwo, tom 9, Warszawa.

Memushaj R., 2003, Për një ndarje tjetër në klasa të foljeve të shqipës, [w:] Studime filologjike $1-2$, Tiranë.

Mindak J., Sawicka I., 1993, Zarys gramatyki języka albańskiego, Warszawa.

Surdulli M. (red.), 1985, Gramatika e gjuhës së sotme letrare shqipe, Morfologja, Prishtinë.

Wiśniewski M., 2005, Dystrybucyjne właściwości odprzymiotnikowych nazw cech we współczesnej polszczyźnie, Toruń.

Эйнтрей Г. И., 1982, Албанский Язык, Leningrad.

\section{Formal Analysis of Albanian Adjectival Derivatives}

\section{Summary}

The paper presents a formal analysis of Albanian adjectival derivatives, carried out in accordance with the proposal of a formal description of word formation (part of methodology presented in Bulgarian-Polish Contrastive Grammar, Volume 9).

This type of description in addition to a characterization of formal, segmental exponents of derivation allows for appearing and signalizing functions of Albanian definite article in word formation process.

Analyzed material comes from the Dictionary of Contemporary Albanian Language (Institute of Language and Literature of the Albanian Academy of Sciences 1984, revised edition 2002) and is nearly $62 \%$ of all lexical adjectival units (about 6100 adjectival derivatives).

Keywords: Albanian; word formation; formal analysis

Słowa kluczowe: język albański; słowotwórstwo; formalna analiza 